\title{
Breast carcinoma metastasis to endometrial polyp (Case report and literature review)
}

\author{
Endometrial polipe metastaz yapan meme karsinomu- olgu sunumu ve \\ literatürün gözden geçirilmesi
}
İlknur Çetinaslan Türkmen*, Nuray Başsüllü, Reyhan Yaşar, Gökçenur Gönenç, Herman İşçi, Mustafa Özgüroğlu, Gülen Bülbül Doğusoy

Department of Pathology (Assist. Prof. İ. Çetinaslan Türkmen, MD., Assist. Prof. N. Başsüllü, MD.), Department of Obstetric and Gynecology (G. Gönenç, MD., Assist. Prof. H. İşçi, MD.), Department of Medical Oncology (Prof. M. Özgüroğlu, MD., Prof. G. Bülbül Doğusoy, MD.), İstanbul Bilim University School of Medicine, TR-34780 İstanbul. Pathology Labaratory (Bio. R. Yaşar), Florence Nightingale Hospitals, TR-34780 İstanbul.

\begin{abstract}
Metastasis to female genital tract are most commonly seen in the ovaries and it is very rare for uterus to have metastasis from extragenital organs. Metastatic carcinoma in an endometrial polyp is exceptional and presented as case reports in the literature. The presented case was a 52 year old woman, having metastatic breast carcinoma of invasive ductal type. She admitted to the gynecology department, with the complaint of postmenapausal bleeding. The pathological examination revealed a hyperplastic endometrial polyp, having a focus of epiteloid cellular infiltration in the stroma. The immunohistochemical staining showed these cells to be CD 10 negative, Pancytkeratin and GCDFP-15 positive. Pathological diagnosis was hyperplastic polyp, with focal carcinoma infiltration (compatible with breast carcinoma). The curettage specimens of the patients being followed for breast carcinoma is frequently seen in the daily routine of the pathology. The probability of metastatic disease must be kept in mind and the whole curretage materials must be evaluated. The pathological examination must be carefully made for the exclusion of a metastatic carcinoma.
\end{abstract}

Keywords: Endometrium, metastasis, breast carcinoma, endometrial polyp

\section{Özet}

Kadın genital sistemde metastazlar en sık overlerde görülür ve uterus için ekstragenital organlar dışından metastaz alımı çok nadirdir. Endometrial polipe metastaz ististani bir durum olup, literatürde olgu sunumları şeklinde yer almaktadır. Sunulan olgu 52 yaşında, metastatik invaziv duktal tip meme karsinomu olan kadın hastadır. Hasta jinekoloji bölümüne postmenapozal kanama şikayeti ile başvurdu. Patolojik incelemede hiperplastik tipte endometrial polip ve fokal bir alanda stroma içinde epiteloid hücre infiltrasyonu izlendi. İmmunohistokimyasal incelemede bu hücrelerin CD10 negatif, Pansitokeratin ve GCDFP-15 ile pozitif olduğu görüldü. Patolojik tanı fokal karsinom infiltrasyonu (meme kanseri ile uyumlu) içeren hiperplastik polip olarak raporland1. Meme karsinomu tanısı ile takip edilen hastalara ait küretaj materyalleri patoloji rutininde sıkça yer almaktadır. Metastatik hastalık olasılığı akılda tutulmalı, materyalin tamamı incelemeye alınmalı ve patolojik inceleme; metastatik hastalığı ekarte etmek üzere dikkatle yapilmalidir.

Anahtar sözcükler: Karsinoma, duktal, meme, tümör metastazı, endometriyal tümörler

Geliş tarihi/Received: September 21, 2012; Kabul tarihi/Accepted: October 15, 2012

\section{*Corresponding Author:}

Dr. İlknur Çetinaslan Türkmen, Patoloji Anabilim Dalı, İstanbul Bilim Üniversitesi TR-34780 İstanbul. E-mail: ilknurcetinaslan@ @otmail.com

Bu olgu sunumu 16-20 Kasım 2011'de İzmirde gerçekleştirilen 21. Ulusal Patoloji Kongresinde poster olarak sunulmuştur. 


\section{Introduction}

Female genital tract is a rare site for metastasis from other organ systems and ovary is the most common site to have metastasis followed by vagina, cervix, uterine corpus and fallopian tubes [1]. The primary sites of these metastasis are mostly breast, followed by stomach, cutaneous malonoma, lung, colon, pancreas and kidney [1-3]. The route of metastasis is via the lymphatics from the overies, but in the case of isolated endometrial metastasis, hematogenous spread should be thought [4]. The histological type of the primary tumor is mostly lobular carcinoma [5-9], as well as reported ductal, metaplastic, apocrine carcinomas $[2,4,10-13]$. We report a case of metastatic breast carcinoma of invasive ductal type to an endometrial polyp.

\section{Case report}

A 52 year old woman, gravida 3, para $2(1 \mathrm{D} / \mathrm{C})$, admitted to the gynecology department, with the complaint of postmenapausal bleeding. She had history of breast carcinoma of invasive ductal type diagnosed 4 years ago, and had modified radical mastectomy with axillary lymph node dissection. There was multicentric, multifocal invasive ductal carcinoma and 8/26 axillary lymph node involvement. There was also bone metastasis. Full curretage was performed for treatment, and diagnosis of her postmenapausal bleeding. The material was hemorrhagic currettage having $4 \mathrm{~cm}$ diameter polypoid mass within. The whole material was revealed for the pathological examination, and on microscopy a hyperplastic endometrial polyp was seen. In one of the sections, a focus of epiteloid cellular infiltration in the stroma (Figure 1, A-B) was observed, at the first look, it was like decidualized stromal cells; but on higher magnification the cells have an epitheloid appearance with vesicular nuclei, and idendifiable cytoplasm (Figure 1, C). At the periphery of this infiltration similar cells were seen in the lympatics (Figure 1, D). The immunohistochemical staining showed these cells to be CD 10 negative, Pancytokeratin and GCDFP-15 positive (Figure 2). Pathological diagnosis was hyperplastic polyp, with focal carcinoma infiltration (compatible with breast carcinoma). The patient was well up to the date.

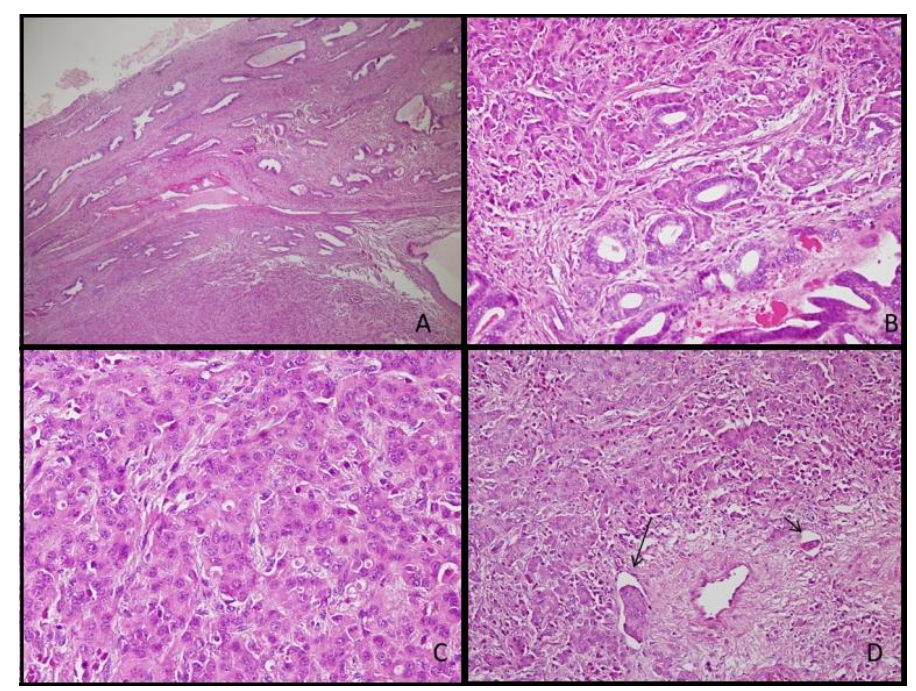

Figure 1. Cellular infiltrate in the stroma of the polyp (A), at higher magnification the infiltrative natüre of the cells, between endometrial glands (B), and the pleomorphic cells with formations of ductular units $(C)$, at the periphery of this focus there was lymphatic invasion (D) of the tumor cells (HE, x100, $\mathbf{2 0 0 , x 4 0 0}$ and $\mathbf{x} 200$ respectively). 


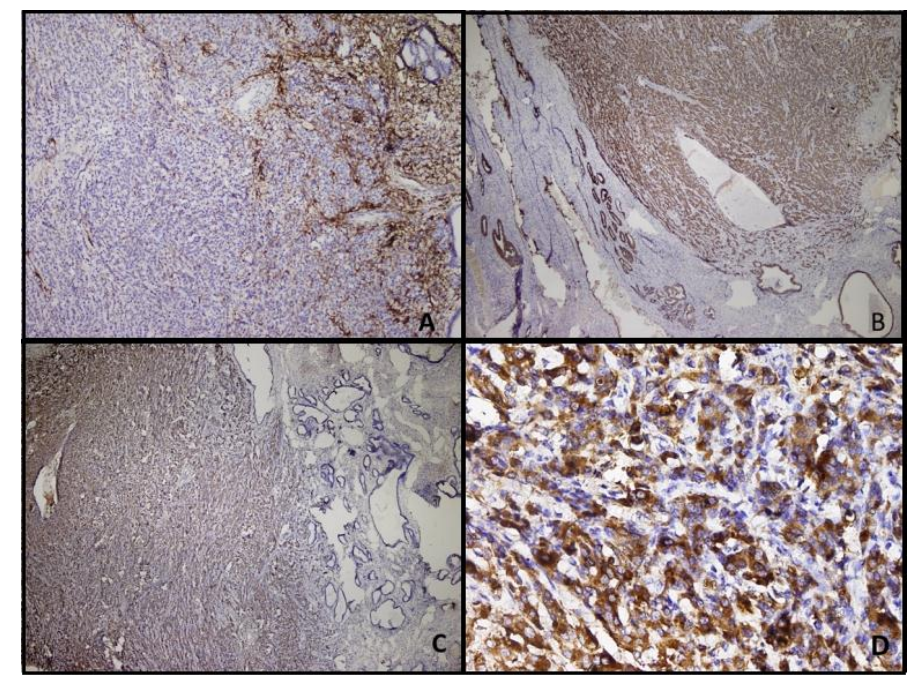

Figure 2. Immunohistochemical study showed the cellular infiltrate to be negative with CD 10 (A), positive with Pancytokeratin (B) and Gross cystic disease fluid protein 15 (C,D) $(\mathrm{x} 200, \mathrm{x} 200,200$ and $\mathrm{x} 400$ respectively).

\section{Discussion}

Female genital tract is a rare site for metastasis and when present, it is mostly from neighboring tumors or by peritoneal implants as the ovaries being the most common organ involved [1]. Endometrium is an extremely rare site for metastasis, and it usually takes metastasis via the lymphatics from ovaries or through contiguous spread from myometrium [1, 13]. When there is no involvement of ovaries or myometrium, hematogenous spread should be thought from distant primaries [4, 13]. Breast is the most common primary carcinoma seen in uterus followed by, stomach, cutaneous malonoma, lung, colon, pancreas and kidney [1-3]. Endometrial involvement, when present, can be a component of diffuse metastasis of a disseminated cancer [11, 14-16] and endometrial involvement is usually diffuse sparing the glands [1]. But isolated metastatic foci can also be seen in endometrial polyps, but these are as case reports in the literature and summarized in the table 1. Polyps are common pathologies seen in patients having Tamoxifen therapy for the treatment of breast carcinoma [1,4]. Tamoxifen related polyps are characterized by glandular metaplastic changes and periglandular stromal condensation [6, 8], but Manipadam et al. [8] also stated that these changes are not unique, in their representation of their case that is unrelated to tamoxifen. The metastatic breast carcinomas to endometrial polyps are presented as case reports in the literature, and the cases are mostly of lobular type [3, 5, 6-9], as well as reported ductal and apocrine types $[2,4,10,12,13]$.

Table 1. Literature review of the metastatic breast carcinomas to endometrial polyps.

\begin{tabular}{|c|c|c|c|c|c|}
\hline Case-author & Patient age & Type of breast carcinoma & Metastasis & Treatment & Follow up \\
\hline Sullivian, 1990 & 83 & Ductal- 6 ya & $\mathrm{LN}$ & NM & NM \\
\hline Aranda, 1993 & 76 & Lobular- 3 ya & none & NM & NM \\
\hline Lambot, 2000 & 70 & Apocrine-4 ya & $\mathrm{LN}$ & RT-Tam & NM \\
\hline Horn, 2000 & 73 & Ductal- 4 ya & none & CT-Tam & $26 \mathrm{mn}-\mathrm{FOD}$ \\
\hline Alvarez, 2003 & 69 & Lobular-4 ya & $\mathrm{LN}$ & CT-Tam & NM \\
\hline \multirow{2}{*}{ Houghton, 2003} & 62 & Lobular-1 ya & $\mathrm{LN}$ & Tam & NM \\
\hline & 92 & Lobular- 5 ya & & Tam & NM \\
\hline Al-brahim, 2005 & 53 & Lobular-4ya & $\mathrm{LN}$ & Tam & NM \\
\hline Açıkalın, 2000 & 58 & Ductal-4ya & $\mathrm{LN}$ & CT-Tam & NM \\
\hline Aydın, 2008 & 60 & Ductal & Systemic & Tam & $10 \mathrm{mn}-\mathrm{DOD}$ \\
\hline Madipadam, 2008 & 70 & Lobular-4ya & & CT & NM \\
\hline Hooker, 2011 & 83 & Lobular, 5ya & Vulva & CT-Tam & $12 \mathrm{mn}-$ Alive \\
\hline Present case & 52 & ductal & systemic & $\mathrm{CT}$ & $8 \mathrm{mn}$ - Alive \\
\hline
\end{tabular}


Endometrial pathologies can frequently seen, in the patients followed for breast carcinoma, and pathological examination should be made very carefully, with evaluation of the whole material and serial sections when required, in order not to miss a metastatic foci. Because as in our case, it can be so subttle that, metastatic focus can be seen only at a small focus in a large mass of tissue.

\section{References}

1. Kurman RJ, Zaino RJ, Norris HJ. Endometrial carcinomas, in Kurman RJ (ed.): Blaustein's Pathology of the Female Genital Tract. Spring-Verlag, New York, 2010.

2. Lambot MA, Eddafali B, Simon P, Fayt I, Noe JC. Metastasis from apocrine carcinoma of the breast to an endometrial polyp. Virchows Arch 2001; 438: 5178.

3. Aranda FI, Laforga JB, Martinez MA. Metastasis from breast lobular carcinoma to an endometrial polyp. Report of a case with immunohistochemical study. Acta Obstet Gynecol Scand 1993; 72: 585-7.

4. Horn LC, Einenkel J, Baier D. Endometrial metastasis from breast cancer in a patient receiving tamoxifen therapy. Gynecol Obstet Invest 2000; 50: 136-8.

5. Alvarez C, Ortiz-Rey JA, Estévez F, de la Fuente A. Metastatic lobular breast carcinoma to an endometrial polyp diagnosed by hysteroscopic biopsy. Obstet Gynecol 2003; 102: 1149-51.

6. Houghton JP, Ioffe OB, Silverberg SG, McGrady B, McCluggage WG. Metastatic breast lobular carcinoma involving tamoxifen-associated endometrial polyps: report of two cases and review of tamoxifen-associated polypoid uterine lesions. Mod Pathol 2003; 16: 395-8.

7. Al-Brahim N, Elavathil LJ. Metastatic breast lobular carcinoma to tamoxifenassociated endometrial polyp: case report and literature review. Ann Diagn Pathol 2005; 9: 166-8.

8. Manipadam MT, Walter NM, Selvamani B. Lobular carcinoma metastasis to endometrial polyp unrelated to tamoxifen. Report of a case and review of the literature. APMIS 2008; 116: 538-40.

9. Hooker AB, Radder CM, van de Wiel B, Geenen MM. Metastasis from breast cancer to an endometrial polyp; treatment options and follow-up. Report of a case and review of the literature. Eur J Gynaecol Oncol 2011; 32: 228-30.

10. Aydın O, Bağcı P, Akyıldız EU, Özgüroğlu M, İlvan S. Metastasis from breast carcinoma to endometrial polyp. Eur J Gynaecol Oncol 2008; 29: 666-8.

11. Meydanlı MM, Karadağ N, Ataoğlu O, Kafkaslı A. Uterine metastasis from infiltrating ductal carcinoma of breast in a patient receiving tamoxifen. Breast 2002; 11: 353-6.

12. Açıkalın MF, Öner U, Tekin B, Yavuz E, Cengiz O. Metastasis from breast carcinoma to a tamoxifen-related endometrial polyp. Gynecol Oncol 2005; 97: 946-8.

13. Sullivan LG, Sullivan JL, Fairey WF. Breast carcinoma metastatic to endometrial polyp. Gynecol Oncol 1990; 39: 96-8.

14. Karvouni E, Papakonstantinou K, Dimopoulou C, Kairi-Vassilatou E, Hasiakos D, Gennatas CG, Kondi-Paphiti A. Abnormal uterine bleeding as a presentation of metastatic breast disease in a patient with advanced breast cancer. Arch Gynecol Obstet 2009; 279: 199-201.

15. Ustaalioğlu BB, Bilici A, Şeker M, Salman T, Gümüş M, Barışık NO, Salepci T, Yaylac1 M. Metastasis of lobular breast carcinoma to the uterus in a patient under anastrozole therapy. Onkologie 2009; 32: 424-6.

16. Sinkre P, Milchgrub S, Miller DS, Albores-Saavedra J, Hameed A. Uterine metastasis from a heterologous metaplastic breast carcinoma simulating a primary uterine malignancy. Gynecol Oncol 2000; 77: 216-8. 